\title{
Editorial
}

\section{Shanghai Ren Jia restaurants (the Shanghai Family Restaurants)}

\section{CHINA - AN OVERVIEW}

The People's Republic of China was formally established in 1949. By 2001, what had begun in turmoil as a 'people's democratic dictatorship' had become a member in good standing of the World Trade Organization (WTO). Already an economic powerhouse, the attainment of most-favoured-nation (MFN) trading status will likely have such a powerful effect on the world's economies that many predict that the 21 st century will be a 'Chinese millennium'.

There are 1.3 billion people in China; more than double the populations of the USA and EU combined. Global product and service providers are literally frothing at the mouth to gain access to the world's largest potential consumer market. Currently, China's per capita national income only ranks somewhere in the bottom third of that of all countries. Buttressed by sound government investment and planning, a perpetual influx of direct foreign investment (China was the second largest recipient of this in 2003, according to the United Nations Conference on Trade and Development), soaring export figures (China ranks third in the world, up two slots from fifth just two years ago), and a good deal of optimism, there is, however, no reason to expect that it will stay there for very long.

Furthermore, China's labour force is some 720 million strong, many employed in the manufacture and provision of relatively cheap merchandise. Most countries cannot hope to compete, and, complain as they might about inequity and loss of jobs, the majority of the world's consumers are simply unwilling or unable to pay the premium prices necessary to buy the domestically produced goods that will support domestic industries. Consequently, more and more investment in and procurement from China is forthcoming. This cycle only adds to China's growing buying and selling power and the speed at which modernisation is occurring.

China, however, is a country with a 5,000-year history. Traditions and lifestyles are deeply ingrained and many places look and function much as they did decades ago, particularly in smaller communities where globalisation has been much slower in coming. It is common for several generations to live under one roof and for grandparents to raise children while the parents work, thus reinforcing long-established customs and ways of thinking. It is inevitable that such a way of life comes into direct conflict with China's current dynamism.

Nowhere is this clash more prevalent than in Shanghai, China's flagship city of the future. In just 20 years, modern skyscrapers have been erected over decrepit, two- and three-storey buildings. Parents who once worked for state-owned en- 
terprises have children who now work for multinationals. Families that had nothing now live in penthouses and drive Mercedes sedans. It is the richest and most contemporary of all mainland China's cities and, as a result, serves as a gateway for anything new that is introduced into China. Shanghai residents are literally inundated with a barrage of products, services, market concepts and brand names that are mostly unknown and largely misunderstood. Unlike their Western counterparts, Shanghai consumers simply have not gone through the attenuated consumer evolution that has, in due course, laid all these concepts on their doorsteps overnight.

It is in this confused setting that the war for brand equity and market share is pitched. Chinese and foreign companies alike battle for the limited disposable dollars of Shanghai's growing middle class. Winning such battles today will evolve into owning China's consumer markets of tomorrow.

Foreign brands have the advantage of novelty and international experience. Chinese brands have the advantage of understanding the tastes and preferences of the markets they are trying to reach. Only brands that can effectively combine the two will ultimately be successful.

\section{SHANGHAI}

Shanghai, in the People's Republic of China, is a buzzing metropolis that is home to approximately 17 million people. With only 0.06 per cent of the country's total area and 1.3 per cent of its population, the Shanghai municipality leads the country in many aspects, including:
- the highest gross domestic product (GDP) per capita in the league of provinces and municipalities, which amounted to above US $\$ 4,500$ in 2001

- the largest GDP among all mainland cities, accounting for 5 per cent of the national total in 2001

- the largest recipient of foreign direct investment (FDI) among all mainland cities, accounting for 9 per cent of China's utilised FDI in 2001

- the second largest exports value among all mainland cities, accounting for 10 per cent of the national total in 2002

- the largest retail sales value of consumer goods among all mainland cities, which accounted for 5 per cent of the national total in 2001. (US Agricultural Trade Office) $^{1}$

Known to be the most sophisticated and discriminating of all Chinese consumers, the Shanghainese are trendsetters for food, fashion and lifestyle choices throughout the country because, among other things, they are willing and able to try out new products and services. Between 40 and 45 per cent of all their disposable income involves food.

In this dynamic environment, the Shanghai Family Restaurant chain has grown into one of the most recognised and successful Chinese restaurant chains in Shanghai in just five years. It has achieved this through in-depth market knowledge, focus, hands-on senior management, and an effective combination of the modern and the traditional that, in a way, is symbolic of Shanghai itself.

Although only comprising 15 restaurants, the success and acceptance of 
the Shanghai Family Restaurant chain in a market riddled with competition from small, cheap, single-unit Chinese restaurants and composed of 17 million pernickety consumers who traditionally prefer it that way is nothing short of meteoric. The smallest Shanghai Family Restaurant is a trifling 1,000 square metres $(10,674$ square feet). The largest is a fourstorey behemoth of some 6,000 square metres $(64,584$ square feet). All 15 restaurants are always full for both lunch turnovers and all three dinner turnovers.

The achievements of the Shanghai Family Restaurant chain in such a short span of time have been phenomenal. Senior management understands, however, that in order to continue their sensational track record, many things will have to change as they adapt their restaurant concept to a rapidly changing China. Mr Xin Guo Cao, the Shanghai Family Restaurant chain's vice-president and one of its original founders, shared his insights into this Cinderella story ${ }^{2}$.

\section{ESTABLISHMENT OF THE BRAND}

Four good friends founded the Shanghai Family Restaurant chain. Their primary business experience included industries like real estate, apparel manufacturing and international trade. As they became more successful, however, they diversified their investments into other industries including the hospitality industry. They co-owned and operated hotels and food manufacturing facilities for a decade before they decided to make a foray into the restaurant industry with the Shanghai Family Restaurant concept.
'Everyone likes to eat', quipped $\mathrm{Mr}$ Cao when asked why the friends chose to enter such a difficult market with no experience. While true, more incisive reasons include Shanghai's rapid growth, the steadily increasing income of its denizens, and the concurrent growth of a real middle class. These circumstances accentuated the opportunity to fill the gap between low-end Chinese restaurants and extremely expensive, high-end ones. But, there was much more to it.

The founders truly understand the people of Shanghai, their tastes and what is important to them. The original slogan was 'Food prepared the way your mother makes it'. The dishes served at the Shanghai Family Restaurants are not just Shanghainese in style, but are representative of the small villages and towns that make up its outskirts. People move to large cities for their careers, but every area of China has distinctive cuisines and tastes that are not so easily duplicated in other places. Consequently, the idea was to serve food that all the people from Shanghai and its surrounding environs could appreciate.

'Not everyone's mother or wife can cook', joked Mr Cao when explaining that, over time, the motto was broadened to a concept that more embodies 'your home away from home'. Joking aside, the partners realised that serving home-style food to consumers who have spouses and parents at home with the time and inclination to cook for them was perhaps not a strong enough selling point to stand on its own merit.

As a result, they catered to the fact that Chinese people are very social and usually have small homes. In order to celebrate or entertain guests, the 
Chinese must go out to restaurants. The founders envisioned a place where people could go out in groups to rejoice, yet for reasonable prices eat in a style commensurate with what they could get at home. Hence the Shanghai Family Restaurants were born. The first restaurant was opened in May 1998.

\section{Target market}

'Our target market is middle-income to high-income, white-collar, Shanghainese people', explained $\mathrm{Mr}$ Cao. Reaching such a large target required the Shanghai Family Restaurant chain to develop an extremely innovative and absolutely distinct methodology.

Each restaurant is in a different district of Shanghai. Each of the city's districts reflects populations with fairly homogeneous characteristics, lifestyles and buying power. These features are, however, somewhat heterogeneous between districts. Consequently, each Shanghai Family Restaurant has a unique design, select menu items, and prices that are tailored to the tastes and preferences of the people in each respective district.

There are several criteria for selecting restaurant locations. First, they must be far apart, such that the restaurants do not compete with one another, and the inhabitants around each are similar. Secondly, the areas must have good economies. Thirdly, there should be a perceived opening in the district for the Shanghai Family Restaurant's particular niche.

Menu items are updated and changed regularly. Ordering patterns are statistically compiled and the ten items receiving the fewest orders each month are dropped from each restaurant's respective menu. Additionally, Shanghai Family chefs are expected to introduce up to ten new menu items per month in order to maintain diversity and appeal.

The discrete menus do not add significantly to the ordering of supplies and maintenance of inventory. There are two centralised buying offices that compete against each other for the distinction of locating the best prices. There are no commissions or monetary incentives involved. Such practices are as yet uncommon in China. The winning and losing buying offices simply receive public pronouncements of their efforts. Shanghai Family's own trucks handle logistics and distribution.

Does it all work? Brilliantly. The strategy of tailoring designs, menu items and prices to each of Shanghai's districts has been a stroke of genius. There is no cannibalisation because patrons do not commute to other districts. Every chair is full, and during holidays, reservations must be made weeks in advance.

The target market definition is, however, slightly inaccurate in that the occupants of the chairs and makers of the reservations are not white-collar workers. Wealthy white-collar workers are spending money in Shanghai's upmarket or foreign restaurants and cafés. Poorer and younger white-collar workers do not eat in the restaurants because the prices are too high and food quality is generally a secondary concern to them. The patrons of Shanghai Family Restaurants may be middle income to high income, but they are more traditional and more, well, family-oriented. Still, Shanghai has these prospects in abundance and the slight imprecision in target market 
delineation certainly is not hurting business.

\section{KEY VARIABLES}

'The most important factors to our clients are price, food quality and restaurant atmosphere, in that order', avows $\mathrm{Mr}$ Cao. So long as these considerations meet with customers' expectations, the Shanghai Family Restaurant chain does not feel the need to change its tactics.

Customer service, as it is known in restaurants in the West, simply does not exist in China. There are no gratuities and interaction with the staff waiting tables in the Shanghai Family Restaurant is kept to a minimum. The Chinese do not believe in eating for expedience, and consequently meals are long, drawn-out processes. More to the point, relatively wealthy though Shanghai Family customers may be, the expense of a group meal makes eating there a special rather than an everyday experience - one that should be savoured slowly. As such, fast service is not given any priority. The training of Shanghai Family staff and expectations for the performance of their duties exactly mirror those of most other Chinese restaurants, and nothing more.

Advertising is likewise kept to a minimum. It is not necessary. The Shanghai Family promise and delivery are so strong that the chain has been able to grow almost completely on the strength of word-of-mouth advertising alone. 'I guess we run the restaurants the way we act ourselves', $\mathrm{Mr}$ Cao commented. 'We believe in deeds more than words.'

In point of fact, the success of the Shanghai Family Restaurants is not just a reflection of the founders' personalities, it is a direct result. Nothing happens without their unequivocal awareness and consent. Although they still run their other respective businesses, they spend each night of the week visiting their restaurants, sampling the food, talking with customers, and making administrative, as well as executive, decisions.

$\mathrm{Mr}$ Xiong Bao Zhang, Shanghai Family's chairman, CEO and one of the original founders, personally hires and trains key personnel such as the restaurants' senior managers and head chefs. He is constantly on the lookout for promising human resource talent, and his intuition with respect to personalities and loyalty is allegedly peerless. Moreover, he stands by his belief in people.

Mr Zhang hired one of the Shanghai Family Restaurant's senior managers when he found him working in a junior position in another restaurant. The head chef of the largest Shanghai Family Restaurant was hired in the same fashion. Not only did Mr Zhang employ these individuals, he later gave them the opportunity to buy shares in the company. This is a benefit all but unheard of for employees outside the circle of investors in Chinese enterprises and their families. On conviction alone, $\mathrm{Mr}$ Zhang elevated their statuses, improved their lives, and in the process created bonds of loyalty that will never be severed.

This controlled, hands-on management style is common in the China of today. Because of its turbulent history, the majority of China's successful senior business people come from poorer backgrounds and had to claw their ways to the top through a mix- 
ture of solid relationships and connections (called 'guanxi'), good business sense gained through trial and error, and a healthy dose of luck. They do not possess highly technical or business educations, and only have faith in themselves and a trusted circle of friends and colleagues.

In contrast, the younger population is extremely well educated and is every day making great strides in business fields such as advertising and international trade, where China has traditionally been found lacking. This new generation of business people does not, however, have the financial strength of the older guard, nor does it yet have their trust. While this may not have as large an impact on modern industries such as computers and telecommunications where younger people are permitted to shine, in the more established industries such as real estate, manufacturing and hospitality, the people who built the industries unquestionably pull the strings.

Direct involvement by the founders has served Shanghai Family very well until now. Their continuing success does, however, have an inverse relationship to their capacity to personally control all aspects of the Shanghai Family business. At least they know it. 'We can handle the number of restaurants we have now with no problem', Mr Cao commented when asked about the complexities involved in personally administering the chain. 'We just can't do much more.'

\section{THE FUTURE}

As of April 2004, Shanghai Family operates 15 restaurants with plans to add several more to the group this year. The founders already recognise that they are very close to exceeding their managerial abilities. 'We never extended beyond the city of Shanghai because we wanted to control our growth and the integrity of our brand', explains $\mathrm{Mr}$ Cao. In fact, even their Shanghai expansion has moved faster than anticipated.

For this reason, Mr Zhang is exploring becoming a franchisee for a Western fast-food restaurant chain. It is his belief that by learning how to replicate a restaurant system on a large scale, he will better understand how to do the same thing with the Shanghai Family Restaurant chain.

'We probably should have a fiveyear plan', said Mr Cao, 'but things in China move too fast for us to think that far ahead'. This is certainly true. In 2008, the Olympics will be held in Beijing. In 2010, the World Expo will be held in Shanghai. Ever-increasing global attention and tourism, combined with Shanghai's staggering growth rate, will mean that there will be more and more things to celebrate and more and more mouths to feed. In short, the Shanghai Family should keep right on growing.

\section{CONCLUSION}

Through a combination of intuitive market savvy, creativity and effective management, the founders of the Shanghai Family Restaurant chain have developed an extraordinarily successful entrant into Shanghai's fast-paced restaurant scene. Their concept appeals to an incredibly diverse and fickle population despite an intensely competitive marketplace. The chain is, however, at a pivotal stage in its evolution.

The growth of the market segment to which Shanghai Family targets its 
offerings will continue to bring direct competition into a market sector that has hitherto been comprised chiefly of indirect competition. Despite a relatively high level of current brand equity, Shanghai Family will have to work much harder to maintain the degree of penetration that it presently enjoys. This will necessitate the delegation of much more responsibility, the attainment of outside expertise, and a great deal more focus upon marketing mix variables that highlight product and service differentiation going forward.

All three aspects may prove difficult for a company that is so clearly the organisational manifestation of the characters of its founding fathers. If the Shanghai Family Restaurant chain continues to exercise the same good judgment that has brought the brand so far so fast, however, we may all have
Shanghai Family Restaurants opening up in our districts very soon.

Mr Zhang explained, however, that with his entire family living in the USA, he simply wanted to create a restaurant that would make him feel the same way he does when he is having dinner at home with his family. Apparently, a lot of people like the way things are done at Mr Zhang's house.

\section{Peter Cohen Director, Beacon Brand Management consult@beaconasia.com}

\section{References}

(1) See http://www.atoshanghai.org and http://www.tdctrade.com/mktprof/china/ mpshh.htm for further details.

(2) All quotes from $\mathrm{Mr}$ Cao are taken from an interview conducted by the author on $22 \mathrm{nd}$ November, 2003. 